811.163.41'373.611

305-055.2:811.163.41

https://doi.org/10.18485/sj.2019.24.1.9

РАЈНА М. ДРАГИЋЕВИЋ*

Универзитет у Београду

Филолошки факултет

МИЛОШ В. УТВИһ ${ }^{* *}$

Универзитет у Београду

Филолошки факултет
Оригинални научни рад

Примљен: 27. 11. 2018.

Прихваћен: 15. 01. 2019.

\title{
УМНОЖАВАЮЕ МОВИРАНИХ ФЕМИНИНУМА НА -(К)ИЊА У САВРЕМЕНОМ СРПСКОМ ЈЕЗИКУ
}

На основу електронског корпуса сачињеног од текстова који су током 2017. године објављени у дневним новинама Данас и Новости, као и у недељнику Време, сачињен је поткорпус именица на -ища, -ка и -(к)ињ $а$ које спадају у мовиране фемининуме. Након неколико општих напомена које се односе на цео корпус прикупљених мовираних фемининума, у овом раду анализиране су именице на -(к)ињa. У разматрање је узета фреквенција ових лексема, њихова творба, значење и употреба.

Кључне речи: нове речи, мовирани фемининуми, феминизација, суфикс -(к)иња, творба речи, семантика, српски језик.

*rajnad@yahoo.com

***misko@matf.bg.ac.rs

*** Овај рад приказује резултате постигнуте током 2018. године у оквиру пројекта Српски језик и ғегови ресурси (178006) који финансира Министарство просвете, науке и технолошког развоја Републике Србије. 
1. МотИВАцИЈА ЗА ИСТРАЖИВАњЕ. Феминизација српског језика је тема која нам се наметнула приликом испитивања шире теме, а то су нове речи у српском језику. Наиме, једна од најважнијих позитивних последица формирања и претраживања електронских корпуса јесте могућност увида у лексичке и остале језичке промене које се дешавају у савременом језику у кратком временском распону који запрема, на пример, једну деценију, па чак и једну годину. Дужност савремених лингвиста јесте да искористе те могућности, да уочавају и описују те промене, као и да скрећу пажњу лингвистичке, али и шире јавности на њих. Корпуси нам омогућавају прилично прецизан увид у језичке промене у савременом српском језику, што лингвистима омогућава утемељене интеревенције на пољу норме савременог српског језика.

Почетком 2018. године, користећи специјализовани претраживач информативних сајтова у Србији, Наслови.нет, као и онлајн архиву недељника Време, преузели смо све расположиве текстове дневних новина Вечерње новости и Данас, као и недељника Време, објављене током 2017. године. Укупна величина корпуса је 14.106.453 речи, од тога из Времена 1.589.494 (11.27\%), из Вечерњих новости 7.437.488 (52.72\%) и из Данаса 5.079.471 (36.01\%) корпусних речи. На основу преузетих текстова направљен је електронски корпус ДНВ2017 и екстрахован његов речник (396.261 различитих корпусних речи) који смо упоредили са системом електронских морфолошких речника српског језика (СрпМР) аутора Цветане Крстев и Душка Витаса (Крстев 2008). Верзија СрпМР коју смо користили садржи више од 5 милиона граматичких облика генерисаних од око 140 хиљада једночланих лема, док је број вишечланих одредница у СрпМР већи од 18 хиљада (Крстев и др 2018). На основу лексике корпуса ДНВ2017 која није регистрована у СрпМР, добијена је листа сасвим нових или релативно нових речи у савременом српском језику, забележених у српским штампаним медијима током 2017. године. Анализирајући ту филтрирану лексику штампаних медија са жељом да утврдимо какве нам је лексичке новости донела година 2017, установили смо, без много муке, да велики број нових речи представљају тзв. мовирани фемининуми (према терминологији Б. Ћорића) или социјални фемининативи (према терминологији П. Пипера). Тако се јавила потреба да се опише тенденција настајања све већег броја ових лексема. У ту сврху је формиран и анализиран поткорпус корпуса ДНВ2017 који садржи примере употребе именица које су изведене суфиксом -ка, -ища и -киња .

2. РодолектологијА. Загребачка лингвисткиња Татјана Пишковић (2018: 16-17), у уводу зборника изабраних радова о језику, роду и полу, пише о пореклу термина родолект (genderlect), (који је, изгледа, већ општепознат) и констатује да се он употребљава још од 1972. године и да га је први употребио В. Б. Дикерсон, што значи да се идеолошки обојено питање равноправности полова у језику решава још од почетка седамдесетих година прошлог века. 
Т. Пишковић је увела термин родолектологија (према родолект, а по угледу на однос дијалект - дијалектологија), чиме се оваквим истраживањима даје статус посебне научне дисциплине у оквиру лингвистике. Ову „науку” утемељила je, 1975. године, Робин Лејкоф својом књигом Језик и женино место. И док су хрватски лингвисти, рекло би се, врло заинтересовани за ова питања (исп. нпр. Брковић и Пишковић 2018), српски лингвисти су до сада пажњу усмеравали, углавном, само на творбу и семантику мовираних фемининума, а изван пажње су остала друга питања „мушког” и „женског” језика (нпр. различите лексичке и синтаксичке јединице у „женском” и „мушком” језику).

3. ФЕМИНИЗАЦИЈА СРПСКОГ И ОСТАЛИХ СЛОВЕНСКИХ ЈЕЗИКА. ПреМа П. ПиПерУ (2016: 38), „распрострањеност социјалних маскулинатива у категорији nomina agentis, гледано историјски, одражава преовлађујуће агентивну улогу мушких особа у привредним и друштвеним пословима у прошлости, а ширење социјалних фемининатива у савременим језицима одражава чињеницу да је данас стање у том погледу друкчије: у већем делу света жене су у друштву и правно, а умногоме и реално изједначене са мушкарцима". Овај процес је природан и директно је условљен променом позиције жене у друштву, па је, како примећује П. Пипер (2016: 38), још одавно уочен у различитим словенским језицима и о томе су писали, „без непотребне политизације” бројни истраживачи. П. Пипер наводи да је 3. Винце писао о томе још давне 1954. године, С. Николић - 1955. године, М. Храсте - 1957, Н. А. Јанко-Триницка - 1966, Р. Ленчек -1972 , Б. Ћорић - 1975. године итд. Тек у новије време ова појава почиње да заокупља пажњу феминисткиња и других бораца за равноправност, тј. почиње да се политизује и да дели лингвисте и ширу јавност на оне који су за доследно спровођење феминизације и на оне који се опиру насилном наметању нових речи у циљу вештачког стварања утиска о језичким доказима о равноправности жена и мушкараца.

П. Пипер (2016: 58) наглашава да „Покушаји идеолошког инжењеринга у граматици, ма чиме се оправдавали, јесу опасни, и граматичари не би смели да окрећу од њих главу као од појава које не завређују научну пажњу. Нормативна граматика не треба да подстиче вештачку граматикализацију било којих језичких јединица, па ни социјалних фемининатива. С друге стране, нормативна граматика не треба ни да спречава или успорава спонтани развој социјалних фемининатива и њихов постепени прелазак из усменог изражавања у писмени вид разговорног стила, а затим и у друге стилове књижевног језика."

Оцењујући процес „феминизације језика” увећавањем броја твореница којима се означава женски вршилац радње или носилац занимања, академик П. Пипер (у Јевтић 2015: 65-66) примећује: „Тај покушај може се ставити у шири социолошки контекст, који неки виде као глобални процес феминизовања друштвеног живота, а има и сасвим јасан политички контекст, јер жене чине већину бирачког тела, које је јефтиније придобијати политичко-граматичком 
демагогијом (понудити им неколико стотина именица женског рода да би се осећале мање „угрожено”) уместо бољим условима за живот и рад. Када би онима који говоре српски биле потребне речи као хирургињ $а$, стручњакињ $а$, преводилица и сл., они би их спонтано створили не чекајући да им то неко одобри, нареди или да им их створи неки лингвиста ма ког пола и ма какве идеолошке припадности био. Речи као учитељица, професорка, докторка, и многе друге, нису настале декретом који су припремили политички подобни лингвисти него их је народ сам створио. Такве речи су говорна и језичка реалност коју нико не оспорава.

[Треба размислити] о женама у српском бизнису, политици, култури итд., о томе зашто се у Србији урушава породица, зашто у Србији скоро половина људи између 20. и 40. године старости живи само, зашто је скоро свака трећа мајка у Београду самохрана, зашто се у овој земљи годишње изврши више од 150 хиљада намерних побачаја итд. То су за жене много важнија питања од тога да ли ће се рећи преводилица, хирургиња, ректоркиња, лингвистииа или некако друкчије”.

Има и сасвим супротних приступа овом питању. Тако, на пример, С. Савић и др. (2009: 11) сматрају да грађење мовираних фемининума представља „простор за језичку креативност” и наглашавају: „Такав приступ позива на креативан однос према језику јер захтев 'учини жену видљивом у језику у јавној сфери' подстиче на то да проналазимо и правимо форме у језику у настојању да остваримо такав захтев" (Савић и др. 2009: 11). Ауторке наводе Предлог Упутстава за употребу родно осетљивог језика у сфери јавне комуникащије, а ово су нека од предложених упутстава: употребљавати доследно форму женског рода за именовање занимања и титуле жена свуда где је то могуће; користити паралелне форме ако се препорука односи и на мушкарце и на жене; користити креативно разне форме родно осетљивог језика приликом обликовања текста; писати титуле и занимања жена у пуном облику, а избегавати писање скраћеница.

Савић и др. (2009) дају регистар мовираних фемининума или социјалних фемининатива, који су на самом почетку XXI века потврђени у изворима које су ауторке поделиле у следеће групе: феминистичка литература, конверзација, стручна литература, медији, речничка грађа, упитничка грађа (Савић и др. 2009: 37).

Обично се мисли да у ове именице спадају оне творенице које означавају женског вршиоца радње или носиоца занимања. С. Савић и др. (2009: 37) груписали су, међутим, ова образовања по значењу, а из те класификације јасно је да је процес феминизације захватио знатно већи број тематских група него што се обично мисли. Ауторке су поделиле ове именице у пет група: 1) занимање и делатност жене (лингвисткиґа, глумица); позиција у хијерархији 
предузећа, установе (ректорка, гувернерка, начелница); спорт којим се жена бави (тенисерка, кошаркашища) или уметност (сликарка, графичарка), магијска радња коју обавља (врачара); 2) жена према звању, занимању, титули супруга/оца (агиница, баронеса); 3) титуле, звања и функције жена (амбасадорка, доценткињ а, секретарка, посланица), 4) следбеница неког покрета или учења (феминисткиюа, мировњакињ $а)$, учесница и припадница групе, покрета (омладинка, ученица, антифашисткиња); 5) начин живота (просјакињь), хоби и активности које нису у директној вези са неком професијом (голубарка), болест, психофизичко својство и склоност (дијабетичарка, алкохоличарка), имовински статус (богаташиц̧а, власниц̧а).

4. МАЛО СТАТИСТИЧКИХ ПОДАТАКА О НАЈНОВИЈИМ МОВИРАНИМ ФЕМИНИНУМИМА У СРПСКОм ЈЕзикУ. У нашој грађи има укупно 207 именица на -ка, 172 именице на -ица и 135 именица на -кињ $а$, из чега се може закључити да је у штампаним медијима, током 2017. године, регистровано бар 500 оваквих именица (а тај број би сигурно био већи ако бисмо у обзир узели све штампане медије у Србији). Очигледно је, такође, да је суфикс -ка, према узорку који смо испитали, најпродуктивнији суфикс у српском језику за грађење мовираних фемининума. Најфреквентнија именица у грађи је представница, која се појављује чак 2.693 пута, а одмах за њом председница - 2.029 пута. Међу именицама на -ка најфреквентније су следеће: министарка (964), директорка (665), канцеларка (459), грађанка (367), а у најфреквентније именице на -(к)июа спадају: кандидаткиюа (134), активисткиња (124), пацијенткиња (91), феминисткиња (50). Већ и ови подаци указују на чињеницу да међу мовираним фемининумима доминирају именице на -ица, и поред тога што је суфикс -ка најпродуктивнији.

Очигледно је и очекивано да је прва класификација ових лексема творбена и да је заснована на суфиксу којим су изведене, па их тако можемо поделити у три групе - на оне које су изведене суфиксом -ка, затим оне које се завршавају на -(к)uњ , а у трећој групи су именице на -ица. Према речима Б. Ћорића (2008а: 200), постоји десетак суфикса у српском језику који имају улогу у мовирању, али се продуктивношћу издвајају, као што смо и ми установили, $-и ц а,-\kappa a,-u њ a$ и -кињ $а$, од којих је „само овај последњи везан искључиво за моцију”.

5. МОВИРАНИ ФЕМИНИНУМИ НА -(К)ИњА У САВРЕМЕНОМ СРПСКОМ ЈЕЗИКУ. ЗбОГ обима грађе, овај рад биће посвећен само мовираним фемининумима на -кињ $а$. О мовираним фемининумима на $-(\kappa) u њ а$ често се пише у вези са њиховом гласовном структуром, јер многи од њих настају од именица мушког рода на -лог, нпр. психолог - психолошкиња. Године 2008, у време када је објављена његова књига, Б. Ћорић их назива необичним. Пажњу му привлачи и боркињ $а$, ,jер је скована по творбеном моделу који није обичан. Прво, од двосложних именица на -/a/u ретко се и прави мовирани фемининум, а, с друге стране, суфиксна корелација -/a/u : -кињ а ретка је у српском језику. У понеким случаје- 
вима моциону форму карактерише сложен изговор, што је чини инфериорном у односу на генеричку форму. У овом контексту спомињана је и именица психолошкиња, али је у дискусији ове врсте најчешће навођена именица архитекткиґа, где се додавањем суфикса доиста ствара тешко изговорљива консонантска скупина" (Ћорић 2008б: 206).

5.1. МОВИРАНИ ФЕМИНИНУМИ НА -(К)ИЊА СА ЈЕДНОМ ПОТВРДОМ У ГРАЋИ. За НеКе од ових именица постоји само једна потврда и оне привлаче пажњу јер указују на нове правце у усвајању ових именица у српском језику: адресаткињ $а$, анархисткињ $а$, антимилитаристкињ $а$, антисрпкињ $а$, антрополошкињ $а$, астрономкиња, багеристкиња, ватерполисткињ $а$, видовњакиња, витешкињ $а$, вишероткињ $а$, гинеколошкињ $а$, дефектолошкињ $а$, докторандкиња, Ђакиња, ексстуденткињ а, ентузијасткињ $а$, епизодисткињ $а$, журналисткињ $а$, инструменталисткињ а, јатакињ $а$, каријеристкињ а, квалификанткиња, кларинетисткињ а, команданткињ $а$, комуниколошкињ $а$, лобисткињ $а$, ловкињ $a$, мецосопранисткиња, монархисткињ $а$, мотоциклисткињ $а$, муралисткињ $а$, мутанткиња, мушкињ а, националисткиња, нихилисткињ а, обоискињ а, перкусионисткињ $а$, перефкционисткињ $а$, питомкињ $а$, полиглоткиња, политиколомкињ $а$, постдипломкињ а, потомкињ а, презимењакиња, психолошкиња, резиденткињ а, референткињ а, рођакињ а, сочијалдемократкиња, статисткиња, стилисткиња, стрипјунакиња, теолошкиња, трагисткиња, уролошкиња, филолошкиња, фолиранткиња, харфисткиња, хомеопаткиња.

На један од разлога због којих многа од ових образовања вероватно неће моћи да заживе и да постану део општег лексичког фонда управо смо скренули пажњу навођењем запажања Б. Ћорића о чињеници да нека од њих имају прилично рогобатну фонолошку структуру. Неке гласовне групе нису једноставне за изговор, на пример -ндк- (докторандкиња), -нтк- (команданткиња), -стк- (каријеристкиња). Постоји тежња за поједностављивањем ових сугласничких група и губљењем из њих сугласника $\partial$ или $m$.

Пажњу привлаче и сложена образовања попут антимилитаристкињ $а$, стрипјунакињ $а$, социјалдемократкиґа, које компликованим и неприхватљивим чини и дужина.

Неколико именица означава женске носиоце типично мушких занимања, па и за њих можемо рећи да немају много шансе да се прошире: багеристкињ $а$, ватерполисткиґа, мотоциклисткињ $а$, а неке се односе на носиоце особина или звања које се обично везују за мушкарце: витешкињ а, јатакиња, команданткиња, питомкиња.

Мовирани фемининуми су још увек (у некој мери) уобичајени само у сфери именица којима се означавају занимања и вршиоци радње. Ипак, појављују се и они који означавају носиоце особине и који још увек делују сасвим необично у српском језику. Такве су, на пример, ентузијасткиња и 
перфекиионисткиња. Као да овакве именице имају два информативна фокуса - један је на особини, а други на чињеници да је у питању женски носилац особине. Чини се да се њима имплицира да постоји разлика у особини или у њеном манифестовању у зависности од пола њеног носиоца.

Међу најнеобичније лексеме из грађе спадају ђакиња [Шарчевић је убрзо проширио подручје борбе, и сад већ ево најављује општу офанзиву на овдашње Ђаке и ђакиње (Време)] и ловкиња [Испуњавамо ли друштвене норме ако жене називамо ватрогаскињама, логопеткињама, возачицама, уролошкињама или ловкиғама? (Новости, 8. 10. 2017)]. Обе ове лексеме, као што нам показује контекст, користе се експресивно, па чак и шаљиво. Њихова употреба није природна.

Необична је квазиименица лошкињ $а$, коју употребљава један колумниста Данаса да би њоме обухватио све именице на -кињ $а$, посебно оне које су настале од именица које означавају мушке носиоце занимања на -лог: - Bише пута је писао да је срећан што су се појавиле психолошкиње и друге -лошкиње како би се избегле граматичке грозоте (Данас, 18. 10. 2017). У овом примеру је и суфикс наведен погрешно, а пажњу привлачи и чињеница да се у експресивној употреби (па чак и у научном стилу) повећава број квазиименица сачињених од суфикса или квазисуфикса од којих су начињене. Тако, на пример, чак и неки научници користе у именичкој служби образовања типа оними (у ономастици, као заједнички назив за топониме, хидрониме, антропониме, ојкониме итд), изми (за бројне апстрактне именице које се завршавају на -изам итд). Оваква образовања су, наравно, неприхватљива.

Поставља се питање шта сазнајемо о употреби мовираних образовања на основу реченица у којима су употребљене.

Неке лексеме су употребљене сасвим неутрално и не носе никакву експресивну или какву другу вредност, а у том неутралном духу су написани и текстови у којима су ове лексеме потврђене: рођакиња, социолошкиња, журналисткиња, астрономкиња, инструменталисткиња (= она која се служи музичким инструментом), мецосопранисткињ $а$, потомкињ $а$, хомеопаткињ $а$, лобисткињ а, статисткиња, теолошкињ а, антрополошкиња, кларинетисткиња итд.

У неким примерима није тешко уочити промовисање феминистичке (само)свести аутора (ауторке) текста: када сам се као дипломирана филолошкиња светске књижевности запослила у Градској библиотеци (Данас, 25. 1. 2017). Ситуација у Србији није другачија у односу на свет -жене, феминисткиње, антимилитаристкиње, су константно под ударом десничарских и државно организованих напада (Данас, 8. 3. 2017). Без пардона изјаснила се као филозофкиња и анархисткиња (Данас, 23. 4. 2017). У манифестацији је учествовало више од 9.500 девојчица и девојака, које су упознавале жене 
које раде као предузетниче, инжењерке рударства, рударске техничарке, минерке на повриинском копу, багеристкиње, менаиерке, директорке фирми, монтажерке, полииајке, народне посланице (Данас, 27. 4. 2017). По повратку из Цириха придружила се приватним окушььағима, на којима се разговарало о феминизму, о руским нихилисткиғама, о идејама једнакости и сочијалне правде (Данас, 21. 6. 2017). Модерне Звончице су велике перфекиионисткиъе, савршено предане послу, амбициозне и самоуверене (Новости, 18. 4. 2017).

Има примера у којима се свесно посеже за мовираним феминунумима да би се постигла експресивност, обично иронија: јатакиња Земунског клана и Дачићева другарица с дна каце (Данас, 31.3. 2017). Испуњавамо ли друштвене норме ако жене називамо ватрогаскињама, логопеткињама, возачицама, уролошкињама или ловкињама? (Новости, 10. 8. 2017).

У неким се примерима мовирани фемининум додаје уз именицу која означава лице мушког пола са жељом да се нагласи да се изречено односи на особе оба пола, па није сигурно да ли би се мовирани фемининум употребио самостално: витезови и витешкиње одбране прекида трудноће (Данас, 27. 1. 2017).

5.2. МОВИРАНИ ФЕМИНИНУМИ НА -(К)ИњА СА ВИШЕ ПОТВРДА У ГРАЋИ. ПрВа КЛасификација прикупљених мовираних фемининума била је заснована на броју потврда у корпусу. Смисао овакве класификације заснован је на очекивању да су лексеме за које постоји више потврда можда већ прихваћене у српском језику, а да оне за који постоји једна потврда тек треба да заживе, па је преко њих могуће утвдити тенденције у настајању и развоју ове групе именица у српском језику.

Ево именица на -кињ $а$ које су забележене у српској штампи током 2017. године и за које постоје више потврда: адвокаткињ $а$, агенткиња, академикињ $a$, архитектиња, астронауткиња, ватрогаскиња, везисткиња, вештакиња, водичкињ $а$, документаристкињ $а$, доченткињ $а$, конкуренткињ $а$, консултанткиња, лингвисткиња, матуранткиња, метеоролошкиња, мигранткиња, музиколошкиња, пешакиња, преваранткињ а, протестантанткиња, психотерапеуткињ а, ревизионисткињ $a$, сопранисткињ $а$, стрелкињ $а$, стручњакињ $а$, суткиња, таксисткиња, теквондисткиња, фавориткињ а, филозофкиња.

Више од 15 потврда проналазимо за следеће именице: кандидаткиња (134), активисткиња (124), пацијенткињь (91), феминисткиња (50), спортисткиња (35), суткиња (35), вештакиња (30), социолошкиња (28), кустоскиња (22), психолошкиња (16), драматуршкиња (15). Ова листа јасно указује да најснажнију потребу за еманципацијом имају жене са хуманистичким образовањем.

У дневном листу Данас има две потврде различитих аутора за именицу академкиња. У једном тексту односи се на академика САНУ Исидору Же- 
бељан, а у другом на Ранку Куић, академика Велшке академије. Закључујемо да лексема академкињ $а$ полако пробија пут према стандардном језику. Лексема је потврђена и у Савић и др. (2009).

Необична именица пешакињ $а$ користи се у администартивном стилу (у полицијским и судским извештајима), што је необично, јер није сасвим јасно одакле потреба да се у овом функционалном стилу, иначе склоном обезличавању, прецизира пол пешака: Саветник тужиоца питао је Бакића којим делом возила је дошло до контакта са којим делом тела пешакиње (Новости, 2. 6. 2017). Ову именицу потврђује и Савић и др. (2009), уз напомену да спада у пасивну лексику и да се користи у феминистичкој литератури.

Стрелкиња је такође нераспрострањена лексема, иако је забележена још код Савић и др. (2009), где је означена као пасивна. У том приручнику регистроване су и варијанте стреличарка, стрељачица и синоним снајперка. У Данасу се Зорана Аруновић назива златном стрелкињом (Данас, 13. 3. 2017).

Именица стручњакиња се појављује у упадљиво феминистичким текстовима: Каже за Данас Данииа Тодоров, стручњакиња за родну равноправност (Данас, 20. 6. 2017). Вредност кампане је и у томе што се ради о волонтерској иницијативи, која је удружила активисткиње, маркетинике стручњаке и стручњакиње, драматуршкиње, медије (Време, 2017). Пажњу привлачи чињеница да међу неологизмима има мовираних фемининума који се лако и брзо шире по свим стиловима и оних који се везују само за феминистички дискурс. Поставља се питање од чега то зависи.

Именица фавориткиња се углавном користи када се мисли на групу жена (женски кошаркашки или рукометни тимови) и обично се употребљава у множини [Кошаркашице Србије виђене су као фавориткиње (Данас, 17. 6. 2017). Водиле су фавориткиње у овом мечу током читавог сусрета (Данас, 2. 12. 2017)]. Мовирани фемининуми се у оваквим случајевима, када се говори само о женама, изгледа лакше пробијају и природније прихватају него када се уместо именице мушког рода за особе оба пола на силу укључују напоредне форме двеју именица од којих је једна мовирани фемининум.

Сличну појаву запажамо и у вези с употребом именице матуранткиња. Обично се користи у множини, и то онда када је цео текст посвећен само девојкама, по правилу у вези са припремом гардеробе за матурско вече [Пожаревачке матуранткиње свечану тоалету могу да приуште по цени од 3.800 динара (Новости, 7. 6. 2017). Сандале и свечане ичиеле за матуранткиње могу се наћи по иени од 3.000 динара (Новости, 7. 6. 2017)].

Када је реч о пословима или појавама које се везују искључиво за жене, мовирани фемининуми се користе, изгледа, без задршке, и у једнини (а не само 
у множини као у горе наведеним примерима): Фатима Ибрахим (22) прва је мигранткиња која се породила у кикиндској болници (Новости, 11. 5. 2017).

У српским штампаним медијима постоји склоност ка понављању језичких средстава за представљање особа о којима се говори у тексту. Тако се, рецимо, испоставља да се сви примери у грађи за именицу везисткиња односе на везисткињу Слађану Станковић (која је погинула у Либији). Велики број примера за вештакињу односи се на вештакињу Мирјану Лабовић (која је учествовала у додељивању деце разведеним, а неподобним, очевима).

Примећујемо да се у више случајева мовирани фемининуми употребљавају у низу: српска академкиња и композиторка (Данас, 11. 2. 2017), архитектиґа и активисткиња Министарства простора (Данас, 7. 6. 2017), посланица Европског парламента и доценткиња на Одељењу (Данас, 4. 5. 2017), Изјаснила се као филозофкиња и анархисткиња (Данас, 23. 4. 2017). Ксенија Атанасијевић била је филозофкиња, феминисткиња, антифашисткиња (Данас, 19. 7. 2017). Марија Магазиновић била је српска филозофкиња, кореографкиња, активисткиња и новинарка (Данас, 28. 6. 2017). За себе каже да је уметница, мигранткиња и близнакиња (Данас, 6. 5. 2017). Мелита Милин, музиколошкиња и директорка Музиколошког института САНУ (Данас, 7. 2. 2017). Стилска улога оваквих напоредних конструкција могла би се препознати у тежњи да се појача порука да жена може бити носилац више друштвених улога, представница већег броја идеологија или занимања, из чега следи да је жена друштвено освешћена, моћна и еманципована.

6. ДелимичАН ПоглЕД нА 2018. годину. Без амбиције да доносимо неке коначне судове о најновијим путевима развоја мовираних фемининума на -кињ $а$ у српском језику, скренућемо пажњу на неке чињенице. Ексцерпирали смо лексеме из ове групе из дневног листа Данас, од 5. октобра до 3. децембра 2018. године, као и недељника Време, од 11. јануара до 6. децембра 2018. године. Формирани корпус ДВ2018 садржи 2.266.656 корпусних речи (облика), односно 164.078 различитих речи (корпусних типова). Од тога је забележено тачно 100 различитих лексема на -(к)иґа, односно 364 облика таквих лексема. У овом мањем корпусу, најфреквентнија именица је активисткињ $а$, а затим следе пацијенткиња и првакиња. Подсетимо се да су три најфреквентније лексеме у грађи за 2017. годину биле кандидаткињ $а$, активисткињ $a$ и $n a-$ иијенткињ $а$, на основу чега опрезно закључујемо да, вероватно, није било великих промена на листи најфреквентнијих мовираних фемининума на -(к) ињ $а$ од 2017. до 2018. године. Други закључак је да је листа ових именица врло нестабилна из периода до периода (из године у годину) јер је условљена дешавањима у друштву. Акуелна друштвена и државна питања избацују у први план одређене лексеме, а затим утичу и на њихову мању заступљеност. Тако се, у 2018. години, у малом корпусу Данаса од октобра до децембра 2018. 
године, налазе бројне лексеме које уопште нису потврђене у знатно богатијем корпусу из 2017. године. Неке од њих су, вероватно, нове, али неке су сасвим уобичајене. Необичније су: басисткиња, бициклисткиња, вицепрвакиња, дебитанткиња, делегаткиња, демостракткиња, дипломаткиња, епидемиолошкиња, колажисткиња, пилоткиња. Чешће се користе: археолошкиња, кадеткиња, продуценткиња. Сасвим су фреквентне: близнакиња, војвоткињ $а$, врмњакиња, диригенткиња, јунакињ а, кандидаткињ $а$, песникињ а, првакиња, пијанисткиња, студенткиња.

У корпусу мовираних фемининума из часописа Време из 2018. године, посебну пажњу привлаче четникињ $а$, терористкињ $а$ (као лексеме за неочекиване реалије), неромкиња (као ознака за прешироку појмовну вредност), мултиинструменталисткиња (као лексема неодговарајуће формалне структуре због творбене сложености и дужине), кокустоскињ (као творенице чије декодирање захтева одређени ментални напор јер није одмах јасна творбена основа на коју се суфикс додаје - кокус-/кокуст-/кокустос-). Ови и многи други примери указују на чињеницу да насилно творени мовирани фемининуми понекад представљају објективно непримерене лексичке творевине, чија одбојност не мора увек бити изазвана реакцијом говорника на феминистичку језичку интервенцију, већ стварним насиљем над језиком.

7. ЗАКључАК. На основу свега што је речено у раду можемо сумирати следеће:

А) У српским штампаним медијима (и у српском језику уопште) увећава се број мовираних фемининума. На основу грађе из Данаса, Вечерњих новости и Времена испоставило се да је током 2017. године у српским штампаним медијима употребљено више од 500 различитих именица које спадају у ову групу. Те именице су изведене суфиксима -ица, -ка и -(к)иња. Суфикс -ка је, према грађи за ово истраживање, најпродуктивнији суфикс у српском језику за грађење мовираних фемининума (207 именица из грађе је творено суфиксом, -ка, 172 именице се завршава на -ица, а 135 на -(к)uњa). Ипак, међу мовираним фемининумима доминирају именице на -ица, јер их је убедљиво највише у корпусу.

Б) Увид у мањи, контролни корпус из 2018. године (који сачињавају текстови из Данаса од октобра до децембра 2018. године и текстови Времена од јануара до почетка децембра 2018. године) показује да исте лексеме из ове групе спадају у најфреквентније (активисткиња, пацијенткињ $а$ ), али да је корпус ових лексема врло различит у ове две године, што значи да је нестабилан и зависан од најважнијих тема којима је заокупљена српска јавност у одређеном периоду.

В) Листа најфреквентнијих мовираних фемининума на -киґа могла би указати на вероватноћу да најснажнију потребу за еманципацијом имају 
жене са хуманистичким образовањем (суткињ $а$, вештакињ $а$, социолошкињ $a$, кустоскиња, психолошкиња, драматуршкиња).

Г) Говорници српског језика полако се навикавају на мовиране фемининуме којима се означавају носиоци занимања или вршиоци радње, али увећава се број и оних именица којима се означава носилац особине (перфекционисткиња, ентузијасткиња).

Д) Неке од ових именица употребљавају се у неутралном контексту којим се не сугерише никаква идеолошка порука (статисткињ $а$, астрономкињ $а)$, а неке се користе скоро искључиво у феминистичкој литератури (стрелкиња, стручњакиња). Има и оних примера у којима су ове именице употребљене иронично (јатакиња Земунског клана). Изненађују примери из административног стила у којима се појављује пешакиња.

Ђ) У неким случајевима, мовирани фемининуми се употребљавају у низу (Марија Магазиновић била је српска филозофкиња, кореографкиња, активисткиња и новинарка). Могло би се закључити да је циљ таквих набрајања наглашавање поруке да жена може бити носилац више друштвених улога што значи да је друштвено освешћена и еманципована.

Е) Има лексема које се у нашој грађи чешће употребљавају у множини. Таква је случај са лексемом фавориткињ $а$, која се обично појављује у спортским извештајима и односи се на припаднице женских спортских тимова.

Ж) Нека од образовања на -(к)иња немају много шансе да буду општеприхваћена због тешко изговоривих гласовних склопова (команданткиња), комплексне творбене структуре и дужине (соиијалдемократкиња), као и због одлуке говорника да употребом неутралне (мушке) форме пошаљу поруку о свом неутралном ставу у вези с овим питањем. Осим тога, неутрална образовања могу се објаснити деловањем закона језичке економије.

\section{ЛИТЕРАТУРА}

Брковић/Пишковић 2018: Ivana Brković i Tatjana Pišković (ur.), Izvedbe roda u hrvatskome jeziku, književnosti i kulturi, zbornik radova 46. seminara Zagrebačke slavističke škole, Zagreb: Zagrebačka slavistička škola.

Драгићевић 2010: Рајна Драгићевић, Лексикологија српског језика, друго издање, Београд: Завод за уџбенике.

Јевтић 2015: Милош Јевтић, Живот језика, разговори са Предрагом Пипером, Београд: Београдска књига. 
Крстев 2008: Cvetana Krstev, Processing of Serbian - Automata, Texts and Electronic dictionaries, Belgrade: Faculty of Philology, University of Belgrade.

Крстев и др. 2018: Cvetana Krstev, Ranka Stanković, Duško Vitas, "Knowledge and Rule-Based Diacritic Restoration in Serbian", in Proceedings of the Third International Conference Computational Linguistics in Bulgaria (CLIB 2018), May 27-29, 2018, Sofia, Bulgaria, ISSN 23675675 (on-line), Sofia: The Institute for Bulgarian Language Prof. Lyubomir Andreychin, Bulgarian Academy of Sciences, 41-51.

Пипер 2016: Предраг Пипер, О социјалним фемининативима у српском и другим словенским језицима, Јужнословенски филолог, LXXII/3-4, $35-65$.

Пишковић 2018: Tatjana Pišković, Uvod u rodolektologiju, Rodni jezici, zbornik radova o jeziku, rodu i spolu, uredila Tatjana Pišković, s engleskog prevela Nevena Erak Camaj, Zagreb: Zagrebačka slavistička škola, $7-35$.

Радић 2010: Јованка Радић, Род у природи, граматици и друштву, Гласник Етнографског института САНУ, LXVIII/1, 115-130.

Савић и др. 2009: Rod i jezik, priredile: Svenka Savić, Marijana Čanak, Veronika Mitro, Gordana Štasni, Novi Sad: Ženske studije i istraživanja, Futura publikacije.

hорић 2008а: Божо Ћорић, Именичка моција, у: Творба именица у српском језику, Београд: Друштво за српски језик и књижевност Србије, 197-202.

hорић 2008б: Божо Ћорић, Граматички род и питање полне дискриминације у језику, у: Творба именииа у српском језику, Београд: Друштво за српски језик и књижевност Србије, 202-209.

\section{ИЗВОРИ}

Вечерње новости, дневни лист, http://www.novosti.rs/

Време, недељник, https://www.vreme.com

Данас, дневни лист, https://www.danas.rs/

Наслови.нет, специјализовани претраживач информативних сајтова у Србији, https://naslovi.net 


\section{MULTIPLYING OF MOVIRANI FEMININUM ENDING ON -(K)INJA IN SERBIAN LANGUAGE}

\section{Summary}

A list of nouns ending on $-i c a,-k a$ and $-(k) i n j a$, called movirani femininum, was excerpted from the electronic corpus which consists of text published in 2017 in daily press Danas and Novosti and weekly magazine Vreme. The nouns ending on -(k)inja were analyzed in this paper, thier frequency, their formation, their meaning and usage.

Keywords: new words, movirani femininum, feminization, suffix (k)inja, word formation, semantics, Serbian language.

Rajna M. Dragićević

Miloš V. Utvić 